\title{
History reconstruction: Third century parallels to 20th century South African Church History - Origen Adamantinus ${ }^{1}$
}

P J Maritz

(UP)

\section{ABSTRACT}

History reconstruction: Third century parallels to 20th century South African Church History - Origen Adamantinus

In this paper a possible third century contribution to Church History reconstruction is considered. This is employed as an example for South African church historians who are dedicated to history interpretation, whether it be from the perspective of: acceptance on face value; justification; verification; criticism or renunciation of rwentieth century historical events and the ways in which they have influenced the prophetic task of the church in South Africa. To this end, a parallel is drawn between third century Origen and a few South African church figures from the twentieth century, which will highlight the church's continuing prophetic ministry.

\section{INTRODUCTION}

It is difficult to portray a singular, homogeneous historical picture of the twentieth century pluralised church in South Africa. This could be ascribed to the divergent denominational histories and affiliations, as influenced by both cultural and political factors. Such an attempt at singular portraiture could, in essence, be viewed as counter-contributory to church consolidation, the eradication of deep rooted feigned perspectives, and to the realisation of the church answering its prophetic calling; in terms of both its internal and external witness.

In similar fashion, it would be unbecoming to consider the third century church in terms of a singular sweep of a historian's paint brush. Thus the shifting and varied points of view on approaching, interpreting and employing early church historical data should be tabled and accounted for. In such a program, ideological and doctrinal diversity, with signified and obscured personalities and their sometimes restrained and other-times over-exposed sentiments, would be an instrumental axle. This instrumental axle would in turn be influenced by functional, inter-linking gears related to personal contributions (verbalised perspectives) made in specific 
situations, and as appreciated or rebuked in accordance to established norms set in retrospect to the consequent events.

Origen Adamantinus is referred to in this article, firstly because the conviction could be expressed that the church's treatment of this devoted son of hers; who devoted his whole heritage and talents to the benefit of the church, should be reviewed, as is the current situation in South Africa in terms of both the over-exposed and the restrained church figures, and/or their verbalised and not-verbalised precepts. In the second place, Origen offers himself as an example of controversy in terms of actual-retrospective appreciation and condemnation of an individual, and the subsequent "canonization" of such sentiments, a scenario very familiar to the South African church in general. Thirdly, Origen is employed as an agent to emphasise the importance of prophetic church history, especially in terms of its healing ministry, as expressed as an internal and as an external witness.

\section{ORIGEN THE HEALER}

Ancient criticism against Origen is often inaccurate and ill-directed ${ }^{2}$. Since Origen was active before mention could be made of an Orthodox theology (185-254 A D), in terms of the current understanding of the term, the then determinable criteria should be taken onto consideration. To Origen this criteria consisted of his interpretation of the Gospels, which included the books of the Old Testament, as well as the tradition and the teaching of the church $^{3}$ (oral and written), of which the Gospels formed part, and which matured from the merging of an own-Platonic/rhetorical, Christian, Hellenistic and North African horizon ${ }^{4}$. Criticism directed against Origen, necessarily emphasises his speculative opinions, indicating technical and doctrinal issues, of which he was a rudimentary exponent, and overlooks his envisaged healing task within the church and society.

Being pre-orthodox, in these terms, his profound unity could be found in his inner knowledge and in his ardent love for the Lords. He was more concerned with "convincing heretics of their errors" 6 , succeeding in leading them back to the church ${ }^{7}$, thus taking his role of teacher and unordained-pastor very seriously ${ }^{8}$ and in leading a prudent life ${ }^{9}$, than he was in egotistically advocating his own speculatory philosophy and inquiries ${ }^{10}$ and sophisticated theological concept ${ }^{11}$.

Origen had access to, and made use of divergent models and teachings to exemplify one of his clearest messages to his fellow contemporaries: a call to live a pure life ${ }^{12}$. He orientated himself in terms 
of the healing Christ offers to all mankind ${ }^{13}$. Thus his controversial apokatastasis doctrine could be seen in defence of this call to a perfected life. In this regard, the rhetorical basis of Origen's teaching was not authority in terms of ecclesiastic superiority, but rather argument ${ }^{14}$. He was thus not imposing doctrine upon his fellow man as "the official teaching of the church", but conveyed it convincingly by expounding its reasonability. This approach manifests itself clearly in his debate against Heraclidus $^{15}$. Ironically, his rhetoric ingenuity is used against him by his later critics $^{16}$.

As is the case with his later critics, his immediate critics were not concerned with a positive appreciation of his healing task, rather seeing him as a threat and being intimidated by his popularity amongst laity and ordained. They thus attacked his person ${ }^{17}$ rather than his teachings. Later critics did not have the sense, the background or the ability to appreciate Origen as an conjectural thinker and healer. They rather had comparatively petty personal doctrinal interests, and via the condemnation of the already condemned Origen, they had a free-way and undisputed aperture for their own interests. The dubious translations of Origen's works also came before the firing range of reflective-devaluation.

It is paramount to read Origen's dogmatic and exegetical works, which are at the root of the most textual controversies ${ }^{18}$ concerning his thought in relation to his practical works and life ${ }^{19}$. The former were written in support of the latter. It would serve the re-evaluation of the controversies best if Origen's personal ministry were taken as beacon alongside that of his persona, schooling and locality ${ }^{20}$. It is thus ironic that while Origen's actions and words indicate the depth of his devotion to Christ and to the Church ${ }^{21}$, the reactions to his fruitful harvest indicate the venom of his initial accusers and the unquestioned endurance against him, based on superficial evidence 22 .

In the process of history reconstruction and interpretation, the primary sources could be found to be misleading in terms of value judgements, appreciation of primary tasks and in terms of "expected results" 23 . These terms tend to manipulate the evaluation of the contributing events, facts and various responses there-to, measured against the historian's own value system ${ }^{24}$ and scholarly background.

D P M Huet ${ }^{25}$ (1827-1895), who was known for his passionate sermons, mission interests and for his literary talents, who defended the "conservative" doctrine against the liberal weekly De Ondersoeker, is easily categorized because he was a foreigner ${ }^{26}$. The fact that Beyers Naudé and his fellow's acknowledged their African heritage, and wished to 
help facilitate the healing process between God's unjustly differentiated children, and criticized "main-stream" apartheid theology necessarily implied that they would be victimised, as were Huet and Origen ${ }^{27}$. The Christian Institute, as was the case with Origen were subject to strong criticism, their envisaged healing task being overlooked, with the emphasis rather falling on technical, doctrinal and ideological issues ${ }^{28}$.

A closer look at the distinguished, possible South African church history interpretations, referring to either the acceptance on face-value, the justification, verification, rejection or criticism of past events which were initiated by or influenced or took place within the boundaries of the church, with its countless denominations and streams, leaves the impression that the twentieth century has been, as yet, a time of not only decadence and blindness, but also of illumination, growth and of profound blessing. It is apparent that the church has not, even since the third century, developed any mechanicism for dealing effectively and fairly with doctrinal and micro-political diversification, over and besides the human factor, in its historiographical representation.

In the evaluation of affinities towards Beyers Naudé, it is evident that the church sustains its stance through a proses of tokenism and antitokenism, depending on the prevailing trend. It could be maintained that Naudé is currently being victimised, though not to the extent that he was previously. Through his being identified as an vehicle to acceptance, association with him (tokenism) is invariably used as an instrument to selfappraisal, in antithetic fashion to the 60's and 70's when dis-association from the same person (anti-tokenism) ensured acceptance in the "dominant" school of thought in the pro-apartheid churches. Within this whole system little appreciation is expressed to Naudé whose actions were based on a localised and immediate reading of Scripture ${ }^{29}$, and on a clear conscience, which had been tested untold times ${ }^{30}$.

For the church in South Africa, as understood in its broadest terms, to contribute to the healing process in the country, it would have to be healing towards its self. This inward healing is also to be seen in accordance with the external systems of which it is part. The second direction of healing, which implies the first, is towards the "external" parties who were influenced negatively by the church's actions and attitudes. Irrespective of the perspective from which church history reconstruction is undertaken, the historians' contribution made to this dual healing process is imperative to the church fulfilling its prophetic and particular ministry towards all involved.

The continued calls to live a just and reconciled life must be seen in this healing light. By emphasising the liberating implications of Christ's 
salvation, which is offered to all, Desmond Tutu was trying to bring about social change in his society ${ }^{31}$. Though he did not develop a doctrine as Origen did, he applied and transformed doctrines which levitate the peril of people unfairly discriminated against by authoritarian doctrines and ideologies $^{32}$. Tutu's tools may be questioned in various circles, however, they were practical, and criticism against him could be seen as using his tools as a conductor away from the issues on hand.

Contemporary debates on church unity and ecumenicism could, to a restricted degree, be compared to the debacles of third and forth century speculations on the trinity, where micro-politics played a far greater role than did the quest for the establishment of the ultimate truth. This is a statement of comparative degrees and not of status quo.

In third century Christian thought the term "trinity" as referring to the Three Persons of the Godhead did not feature. Even so, individuals such as Origen were attempting to convey, in human terms, the mystery surrounding God's Person and Nature ${ }^{33}$. Similarly, the term "homoousious" is foreign to Origen's thought, though being present in his work ${ }^{34}$. In search of Origen's misplaced healing considerations, the historian has to discount both the inherited tradition and the lack of primary sources, thus calling for imaginative contemplation, based on few cues, and for an awareness of own locality.

In the twentieth century, up and until the 1970's the term "racist" did not feature in quotidian speech, though being very present in practice. Ecumenical initiatives were only serviceable and acceptable to the extent in which they did not interfere with prevailing ideologies. Ecumenics thus being used as an elitist "buzz word", geographics rather enjoying the lime light than the Spiritual unity. The prophetic and consequent healing incentives were thus snubbed, being directly reflected in the divergent historiographical activities of twentieth century South African Church historians.

\section{ORIGEN THE SPECULATOR}

Origen's philo-exegetical methodology is far too complex and sophisticated for contemporary analysts to possibly negate him on grounds of secondary sources, without indicating appreciation for his primary concerns and interests. Further complicators are his academic background, his modest but prolific capacity to reason, and his sturdy yet sensitive disposition. Origen's dedication to the church and his devotion to and deep-rooted faith in his Saviour was not only an example to his contemporaries, but to twentieth century believers too. 
Reaction to Origen's speculatory nature, would rather be influenced by the reactor's own status and locality than by Origen's unorthodox preorthodox nature. In terms of his scripturally-based methodology ${ }^{35}$, which is closely interwoven with his locality starts with a literal reading of the text. This is a well known fact ${ }^{36}$, but is whitewashed by his highly sophisticated deductions and his other exegetical tools ${ }^{37}$. Unfortunately, much interpretation depends on Rufinus, who, as he admitted himself, ironed out many "perceived inconsistencies" 38 . This is often the resulting situation after editors, translators, and interpreters who contribute to the production and accessible making of original works are given a free hand. It would thus be imperative to account for Rufinus' own relation to Origen and locality, starting with his church affiliation, his understanding of Greek rhetoric and philosophies, and his personal vendetta towards the man whose works he so "aptly" translated.

One of Origen's greatest strengths was his ability to verbalise his thoughts ${ }^{39}$. Due to the complex and sophisticated argument he uses in his rhetoric, Origen's primary intended audience would have to be kept in cognisance, especially concerning their philosophical-doctrinal responsiveness there-to. Unfortunately comparative studies between Origen and his contemporaries, such as Plotinus, bear little fruit towards unravelling Origen's highly spirited written output ${ }^{40}$. As such, Origen dictated directly to scribes whereas Plotinus' Enneads are the product of collected "class notes" as compiled and edited by his student, Porphyry ${ }^{41}$. There are many correlations between Origen and Plotinus in terms of locality ${ }^{42}$, but because their primary concerns differed, these correlations must always be seen in context. Thus, when Plotinus' Three Hypostasis doctrine is used as tool to unravel Origen's thoughts on Christ's Deity, the results of such an exercise could only be appreciated on face value.

is in Origen speculated ${ }^{43}$ to ameliorate his theory formulation, which would serve his primary task. Thus, his thoughts could be described as the tools he used in his expositions. His terminology then being instruments for conveying his thoughts. It would therefore be instrumental to interpreting and understanding Origen to pay attention, rather to his thought systems and argument development, than to his vocabulary44. Jerome or Athanasius did not know, or refer to Origen as supposedly having used the terms, when they would have referred to Origen had he done so, then how could he have later been condemned for having "used" them?45.

"The language of theology was but assuming shape under their processes" in the third century ${ }^{46}$. Theological vocabulary had not yet been fully systematised, nor their meanings, or that signified by their use been 
established in a constant mode. It would therefore be even more difficult to itemise or define pre-Nicean word use in direct relation to Nicean or postNicean word use and choice. This is said with the acknowledgement that a words (lexical item) significance, connotations and use may and does change over any in variable span of time. The church historian should thus guard against etymological studies or vocabulary glosses of doctrinal terminology.

Origen's call to live a pure life ${ }^{47}$ could on face value be explained as being merely moralistic. However, it should be remembered that it is based on the "apostolic teaching of the Soul" ${ }^{48}$, and supports his primary task of ministering healing ${ }^{49}$.

When "leftist" church leaders were categorised as "social gospel" 50 , "liberal"s1, or "socialist" 52 , after making calls on fellow Christians ${ }^{53}$, their messages were often degraded to the political and moralistic ${ }^{54}$. It would seem that the critics were more predisposed to speculation than those humiliated by the austere reproaches ${ }^{55}$.

Though different terminology (e g contemplation, meditation, theologization, systematisation and reflection), is often used to disguise "speculation" in the South African context, the primary process remains similar. So too, modern rhetoric is often used to categorise and to shift the emphasis away from that symbolised. Thus, in language and argument analysis (both written and oral), distorted perspectives may be identified, and their subsequent effects on both macro and micro levels be determined. Selective. or elitist church history reproductions would then be easier avoided.

A further complicator in South African church doctrinal language usage and reception, can be ascribed to the ideological polarisations. This statement must automatically be qualified as a gross generalisation, because within the various church denominations differentiated voices could be heard; various of these were stifled and others were presented as the "official voice of that particular church". This disposition is further complicated by diverse micro-political ambitions and favour seeking. For example. The "traditional Afrikaans churches" reception of "traditional English churches" 56 doctrinal language did not help stall the deteriorating relations ${ }^{57}$. The English churches were often associated to, and placed in the company of "undesirables", through irrational labelling. Deduced accusations were thus easy to draw ${ }^{58}$.

Faith commitments, theologies and politics are heavily conditioned by class interests and particular ideologies ${ }^{59}$. It could, therefore, be justifiable to state that as the different classes were polarised in the 
country, largely corresponding to racial grouping and to ideological leniency, the understanding and interpretation of expressed thoughts would differ in the different church communities, irrespective of denomination. Thus, the history of Black Conscience theologies could be seen as both opposed to and as the counterpart of "white" (Arian) theologies, in the fulfilment of prophetic ministry.

As the developing language of reconciliation is receiving attention in South Africa ${ }^{60}$, perspectives are changing, which is testimony of the seeds planted to this effect at the turn of the last century and at the commencement of the twentieth century. Thus the fruits of positive twentieth century speculations may be seen in both a contribution to "the process of what could culminate in a democratic, just and kinder social order" 61 , and to the church undergoing a healing process internally, resulting in the fulfilment of both a prophetic internal and external witness.

\section{POPULAR ORIGEN}

Each and every school of thought has its own exponents and critics. Divergent reactions to any perspective would be accentuated to a far greater extent if any antagonist, as person, with or without writings and/or actions deeds were the topic on hand. Regardless of such a persons profile, his value would invariably be determined by the lime-light enjoyed.

In South Africa a number of individuals could be identified as having spoken for a cause, and then being victimised, but also revered. So it was with Ambrose Reeves, as with Joost de Blank, Desmond Tutu, Beyers Naudé and Frank Chikane. Not only did they enjoy international recognition, but their local popularity was more often than not overshadowed by technicalities, inverted propaganda and an attempt to lessen positive media coverage. The result was an incongruity between local and foreign press. This fact made Christians and other observers from abroad rather suspicious.

In not too similar fashion, later observers of early church history should be made wary of divergent voices; not only in terms of documentation on face value, but also in terms of critical and meta-textual analysis of the events.

Origen not only enjoyed support under the prominent bishops ${ }^{62}$, but was also widely recognised, amongst heathens and Christians, as a very competent teacher. In hindsight it could be claimed that Demetrius offered Origen the position at the head of the catechal school, so that Origen's popularity would brush off on him. Unfortunately this was not the case. It 
could also be postulated that Demetrius offered him this position to "keep a tab on him" ${ }^{n 3}$ Even as late as the 7th century, his popularity would count in his disfavour. Fortune was on his side, few people today would be acclaimed for following the "philosophical life style"64.

He must have had an appealing personality, apart from his immense intelligence and ascetic inclinations, which were highly revered in his day. Behaviourial studies would probably indicate that he used his life style and writings to safeguard his weaknesses. His one weakness being his inability to defend himself personally, on a micro-political level. This is often a weakness of highly intellectual people, who are more at home debating metaphysical or spiritual truths, and ensuring the success of a project than they are in protecting and caring for themselves. For this reason he would be popular, but also exposed to adversaries.

Origen was also very influential. The large number of his heathen students who converted to Christianity, and died as martyrs testify to this fact $^{65}$. It is not sure if Porphyry is referring to the same Origen, but it could well have been, when he reflects on one of Plotinus' lectures which Origen attended. Before Plotinus brought the session to a pre-mature end he is quoted as saying: "It damps one's enthusiasm for speaking when one sees that one's audience knows already what one is going to say66". Further, Origen's success as an advocate for the "orthodoxy of faith" 67 would have made him a firm favourite amongst the bishops.

In comparing Ambrose Reeves to Origen similarities in tendency can be detected; where adversaries will find any weakness to exploit. Unfortunately, it seems to be common practice amongst Christians to do so, using "official mediums" to cower behind 68 .

\section{ORIGEN, THE CONDEMINED}

The paradox in the story, is that there are countless unrecorded Origens in smaller church communities. Not only are the church "celebrities" victimised, but also numerous silent voices can be heard, who were and are being suppressed for reasons other than those offered, or as in the case of Ambrose, would rather tolerate the situation than being extradited. This apart from those who do experience such extradition from a community for "opposing" the community leaders in terms of eradication of corruption. It must also be acknowledged that this aspect has been over simplified, and is both more complex, sporadical, and infrequently contrary.

The third century had no documented church law, discipline, policies or procedures as is the practice today, other than the holy Scriptures. 
Ironically, Origen's scripturally-based expression of devotion, and fear of himself, was rebuked through a different approach to scripture, though not more literally. Problems generally present themselves when Scripture is interpreted with an "elitist" approach. Both Origen and Demetrius are guilty of this, but does not justify either our continual escapistcondemnation of such practices or participation there-in.

\section{CONCLUSION}

Through the thin paint strokes a particular angle, of which there are many, is mused upon, permitting a perspective on a faded picture of a gifted but denied flower of the church. This contemplation should stimulate thought and reflection on the healing and prophetic ministry possibilities South African Church Historians carry.

In considering a possible third century contribution to Church History reconstruction in South Africa, it has been found that it serves an example for South African Church historians who are dedicated to history interpretation, whether it be from the perspective of: acceptance on face value of the delivered verdicts or of the status quo; justification of such verdicts, or of the historians locality in relation to that of his indirect subject; verification if it be felt required; criticism or renunciation of twentieth century historical events and the ways in which they have influenced the prophetic task of the church in South Africa.

From the indirect parallel drawn between third century Origen and a few South African church figures from the twentieth century, the importance of the church's continuing prophetic ministry has been emphasised.

\section{NOTES:}

I P J Maritz is a research assistant in the Department of Church History, Faculty of Theology (Section B) at the University of Pretoria.

2 P C Hanson, "The influence of Origen on the Arian Controversy", in: Origeniana Quarta (de Referate de 4. Internationalen Origeneskongresses), Innsbrich-Wien 1987, 411.

3 See Eusebius, Historia Ecclesiastica VI.II. 14. See also Origen, De Principiis, Preface.5.

4 See J W Trigg, Origen: The Bible and philosophy in the third century church, ... 1983, 11. See also Historia Ecclesiastica VI.II. 7.

5 E Osborne, "Origen: The twentieth century quarrel and its recovery", in: Origeniana Quinta (Papers of the 5th International Origen Conference), Leuven 1992, 27. 
6 F Crombie, "Introductory note to the works of Origen", in:. The Ante-Nicean Fathers vol IV 1976, 224.

7 Trigg, ibid, 174-176.

8 H Croutzel, Origen, Edinburgh 1989, 153.

9 Historia Ecclesiastica VI.II. 7.

10 Ibid VI.II. 9.: Origen puzzled his father with inquiries for the true meaning of the inspired Scriptures and thus busied himself with deeper speculations.

11 G L Prestige, Fathers and heretics: Six studies in dogmatic faith with prologue and epilogue, London 1984, 43.

12 See R L Akers, The perfected soul as exegetical goal in Origen's writings on the Songs of Songs, PhD Dissertation: Northwestem University 1987. See also De Principiis V. 6. This is not necessarily a "key" to Origen, but it is a useful tool for the purposes of this article.

13 Origen: Commentary on John VI. 37.

14 E Osborne, ibid, 30.

15 See De Principiis IV. Compare to philosophical-rhetorical devices and techniques. Note: More attention should be paid to the questions and their formulation than to the answers; to the style and its implications than to the content; to the purpose of the debate than to its content, as against a third century frame of reference and locality. A good German translation is available in A Hiersemann, Origenes: Das Gespräch mit Herakleides und dessen Bischofskollegen Über Vater, Sohn und Seele. Die Aufforderung zum Marn rium, Stuttgart 1974, 27-44.

16 See below under Origen the condemned.

17 Demetrius' condemnation of Origen evolves around firstly for addressing bishops as an unordained, and secondly for his illicit entrance into the presbytery as an eunuch. Origen's downfall may be said to lie in his personal devotion and in the ferocious jealousy which raged against him. See Historia Ecclesiastica VI.VIII. 3-4. Eusebius indicates the ironic change of heart in Demetrius.

18 Distinction is made between textual controversies relating to Origen's surviving works and the extra-textual controversies which relates, amongst other issues, to his denied canonization as a saint.

19 Crombie, ibid, 224: “... the interpretation of a text which departs most from its natural rendering is commonly the worst".

20 Locality is used in this context as a generic for both temporal and geographical considerations, gentility and cultural perspectives, affiliations and disassociations.

21 See R A Greer, Origen: An exhortation to marnrdom, praver and selected works, Toronto 1979. See also Historia Ecclesiastica Vi. VIII: "There are eunuchs who made themselves eunuchs for the Kingdom of Heaven above (Mat 19:12)

22 1) The vast majority of Origen's works were burnt. 2) Rufinus admits to textual "white washing" in his "Prologue" to Origen's De Principiis. There is obvious incongruence between the intended and the expressed in terms of the above. See also Origen the speculator below. 3) The paradox: Demetrius used Scripture (Deuteronomy) to refute Origen for literally following Matthew 19:2. The 
second refutation against Origen has never been withdrawn by the broader church, because of implied deductions. See endnote 3 above and endnote 29 below.

23 With this concept the problem of historic stock responses or mirror reading is raised. The culturally and scholarly biased hermeneutical approaches also pertain to this aspect.

24 See T Eagleton, Literary theory: An introduction, Oxford 1988, 10-15 et al.

25 Huet mist be seen as at least one "foreigner" who disjoined culture and religion in Africa in terms of the conflict between the "privileged" and the "underprivileged", and their status before Christ. He had a good grasp and understanding of the prevailing discrepancies, and defended the "under dog".

26 P B van der Watt, Die Ned. Geref. Kerk 1834-1866, Pretoria 1977, 130.

27 I C Marais, "Die N.G. Kerk en die regverdiging van apartheid" in: Kerk en Wêreld 8 (1986), 98-101. The Christian Institute was banned in 1975.

28 See for example: P R Buitendag, Rondom Cottesloe: Is Dr A.H. Luckhoff se beoordeling van die optrede van die Nederduitsch Hervormde Kerk van Afrika korrek en geldig?, Unpublished BD thesis, University of Pretoria, 1980. See also: A H Lückhoff, Cottesloe, Cape Town 1978.

29 See endnote 15. Aiso: "Judgement of the findings of the church conference (Cottesloe) can only be based on ... the Word of God. Theological pronouncements demand theological reflection, and if this is considered from any other angle, the truth becomes blurred ...". Quotation from Maandbrief van die NG Gemeente Aasvoël 2/3 (1961) in: C Ryan, Beyers Naudé pilgrimage of faith, Cape Town 1990, 65.

30 See especially: B Naudé, My land van hoop: Die lewe van Beyers Naudé, Cape Town 1995, 109-123.

31 See for example paragraph: B H Bam, "Truth and reconciliation", in: B N Pityana \& C Villa-Vicencio (eds), Being church in South Africa today, Johannesburg 1995, 48-50.

32 See D W Ferm, Third World liberation theologies: An introductory survey, New York 1987, 65.

33 See Commentary on John II. 2: "In what ways the Logos is God. Errors to be avoided on this question".

34 P C Hanson, ibid, 1987, 411. See also Capinula XI of the Ecumenical Council of Constantinople (553). It may be said that Origen had been anathematized to disnupt the Origenists present at the council - thus being used as "a vehicle to disruption". The only previous "official" anathematization against Origen was his being implied in the refined formulation of Canon 1 of the 1 st Ecumenical Council of Nice (325).

35 See Letter of Origen to Gregory III. See also De Principiis Pref. 4.

36 See P Gorday, Principles of patristic exegesis: Romans 9-11 in Origen, John Chrysostom and Augustine, New York 1983, 34-39 \& 45. See also K J Torjesen, Hermeneutical procedure and theological method in Origen's Exegesis, New York 1986, 1-3.

37 Origen's exegetical tools which he used in service of Christianity include: "the parts of the philosophy which are fit ...", and "... as much of geometry and astronomy as may be useful ...". Under philosophy Origen includes: 
"geometry, music, grammar, rhetoric and astronomy ...". To this list Origen also adds prayer. From: Letter of Origen to Gregory $I$.

$38 \quad$ See endnote 17 point 3.

39 Commentary on John V.

40 See for example W H C Frend, Saints and sinners in the early church, London $1985,80$.

41 Porphyry, "On the Life of Plotinus and the Order of his Books", in: "Plotinus" 1 (Loeb Classical Library), 24-26.

42 Both were students of Ammonius Saccus, and spent large portions of their lives in Alexandria. Compare Eusebius" "Life of Origen", Historia Ecclesiastica VI and Porphyry's "Life of Plotinus". See also P Cox, Biography in late antiquity: A Quest for the holy man, Berkeley 1983, 102-107 and 134-136.

43 Origen would readily have been able to refer to Clement's Handbook of knowledge, which could have served as guidelines for the development of his arguments.

44 Origen only mentions the "Three Hypostasis" once in Commentary on John II. A H Logan, "Origen and the Development of trinity theology", in: "Origeniana Quarta", 1987. For a summary of Origen's views on Deity see De Principis IV. 4.1.

45 See endnote 29 and Canon I of the Quitisext council held in Trullo (692), where his speculations were attacked electively and out of its philosophical context.

46 Crombie, ibid, 223.

47 De Principiis, Pref. 5.

48 Ibid.

49 See Akers, ibid, 16.

50 For a positive reflection on Social Gospel see $\mathrm{H} J$ Cane, “Theological reflection on Black Theology", in: We are one voice (Edited by S Maimela \& D Hopkins), Cape Town 1989. For negative connotations see Marais, ibid, 101.

51 For perspective see L \& C Boff, Introducing liberation theology, New York 1988.

52 See A F McGovern. Liberation theology and its critics: Towards an assessment, New York 1990, 58-61.

53 See various essays in L Tlagale \& 1 Mosala (eds), Hammering suords into ploughshares (Essays in honour of Archbishop Desmond Tutu), Trenton 1986. See also J B Gardener's poem "Christ Enough", in: D Tutu, An African prayer book, London 1995, 85. Compare the call from political parties, e g ANC National Executive Committee Statement of January 1990: "Faith in the Struggle", in: Walshe, ibid, 145.

54 The contrary to this is also true: See for example C Villa-Vicencio, Trapped in apartheid: A socio-theological history of english-speaking churches, New York 1988, 139-143. Such calls also promoted negative responses due to their inherent nature versus receptor community permissibility. For example: Ben Marais and his book from 1952, Die kleur-krisis en die weste. For a brief orientation into book, response and locality to Beyers Naudé see P Randall (ed), Not without honour: Tribute to Beyers Naudé, Johannesburg 1982, 12-13.

55 The often cross perspective labelling was invariably received as such by critics' followers, who in turn would "rewrite" the non-qualifications using own frames 
of reference. Thus, all "rightists" would be related to Naziism, and all "leftists" to communism, to generalise the obvious and to obscure the undercurrent similarities of system.

56 To use gross generalisations.

57 Lückhoff, ibid, 11.

58 Buitendag, ibid, 4-5.

59 Walshe, ibid, 11.

60 Compare to 2. Origen the healer above, with accompanying endnotes 1-7. See also Villa-Vicencio, ibid, 7-8, on his request for a South African "post exilic" Theology, which immediately insinuates the Old Testament post exilic theology, and could equally reflect upon the subsequent Pre-Nicean/Post-Nicean theology distinctions, apart from the various retrospective perspectives.

61 C Villa-Vicencio, A theology of reconstruction: Nation building and human rights, Cambridge 1992, 7-8.

62 See Historia Ecclesiastica VI.XIX. 16-19.

63 Studies incorporating perspectives offered by the Behaviourial Sciences would be most helpful in this regard. Compare with political censorship, banning, imprisonment and other such activities from the South African near-history.

64 Dion, Plato's friend also followed a similar life style, and was held in contempt by his nephew, Dionysius, for attempting to introduce the philosophic life style in Sicily. See Plato, Epistle VII 327A-E.

65 Historia Ecclesiastica VI. IIV. 13 - V.1.

66 Life of Plotinus, 14. 24-25. Whether this refers to the Christian or to an "other" heathen Origen is open to debate. Though the dual-Origen theory enjoys broad support, all the substantiations to this effect can be accounted for. In addition to this, all the arguments in support of a dual-Origen hypothesis are not conclusive. See also ibid, 3.20 and Plotinus, Enneads I, Loeb Classical Library, Oxford 1966, 10-11, footnote 1. Porphyry claims to have known the "Christian Origen" personally. Witness to this effect can be found in Eusebius' reflection on Porphyry's lost Against christians. See Historia Ecclesiastica VI.XIX. It mist be remembered that Plotinus was "un-Christian" while Porphyry was "antiChristian", but still holding Christ in high esteem, much in the line of Ghandi after his experience with "Christians" in South Africa.

67 Historia Ecclesiastica VI.II.

68 The General Synod (1966) decided to reject the Christian Institute, as JC Marais reports: "... as 'n dwaal rigting wat die suiwer leer ondermyn, die goeie orde in die kerk ondergrawe en twee-drag onder lidmate saai, dat ampsdraers en lidmate hulle uit lojaliteit teenoor hul kerk aan die Christelike Instituut moet ontrek". The Dutch Reformed Church members in the Christian Institute wrote a response which was handed in at the 1970 General Synod, but was not dealt with due to a lack of time. The 1974 General Synod response was not positive either. See J C Marais, ibid, 98-101. 